real estate comprises vast forest lands, copper and iron mines, and waterfalls representing 100,000 horsepower. Its ironworks at Domnarfvet are the largest in Scandinavia, and the largest using charcoal fuel in the world.

\title{
Transportation History Through The Newspapers
}

A short time ago the Society came into possession of what is probably a unique collection. It is a potpourri from the history of transportation, fourteen bound volumes, and nearly twice as much loose material in boxes and folders - newspaper clippings, some of them dating back to the beginning of the last century, on turnpikes, canals, stages, taverns, railroads, steamboats, ferries, ships and shipbuilding, coal, express-riders, and every subject which could conceivably have had anything to do with transportation, including the ubiquitous lottery. The books are liberally illustrated with engravings, sketches and prints of the commercial cities of the world, scenes along the route of canals and railways, coaching parties and the like. This collection was the work of the late Mr. Benjamin Thomas Hill, of Worcester, in his spare time. It was acquired through the interest of Mr. Hill's heirs, and the coöperation of many of his former associates in the city of Worcester.

The books are arranged chronologically, but there is an elaborate index according to subject. Turning over the leaves of one of the volumes, the reader will find, perhaps, a pencil sketch of Cincinnati in 1829 , with a topheavy old side-wheel steamer in the foreground, followed by a hopeful announcement that work is to be commenced immediately on the Baltimore and Susquehanna Railroad. Rapid progress will undoubtedly be made, indeed twelve miles of the road should be completed within the year, "affording a practicable demonstration of the value and advantages of railroads." The extract continues in a bitter tone about a proposed improvement of the river Codorus by the citizens of York, suggesting that "their liberal, enlightened, and patriotic neighbors of the Aurora have a town meeting called in Philadelphia, to petition the legislature of Pennsylvania for the erection of a wall at least fifty cubits high, at the Maryland line, and thus effectually put a stop to the daring attempt of the Baltimoreans, and the people of Southern Pennsyl- 
vania, to commit the treasonable act of improving the approach to their natural and best market."

On the page after this glimpse at the jealousy between commercial cities in the earlier stages of their development appears an advertisement of the opening of the "houses at Shocco Springs," a North Carolina watering place, "nine miles South of Warrenton and three miles from the Northern and Southern main Stage Roads." For the benefit of those who have not already visited Shocco, the proprietress feels it necessary to say, "that the buildings are sufficiently numerous, and conveniently arranged for the reception of a large assemblage. The private apartments will afford ample retirement to those who prefer it, and the public Halls are abundantly spacious to receive all who may desire company, and where music and dancing can be enjoyed by such as delight in it."

Arrangements will be made for divine service on Sundays, so that "such visitors as may choose can attend preaching without inconvenience."

"In addition to the valuable Medicinal qualities of the Shocco waters, it is located in the most healthy part of the country, surrounded by a polished society, where the invalid can be restored to health in an agreeable circle."

Prices are a dollar per day for grown people, "children and servants half price."

Elsewhere are announcements of the sailing of ships: the brig Calo, Capt. T. Percival, will positively sail for Baltimore on Saturday (wind and weather permitting); "the fast sailing schooner Boston, Clark, master will take freight low for said port (Philadelphia), and positively sail on that day;" the schooner Romeo will take freight for New York, Washington, Alexandria or Georgetown, at a low rate, if offered immediately.

Farther on it is stated that news from Valparaiso shows American whalemen to be outstripping all competition, and that the fame of their enterprise extends to every island from America to Japan, and from New Zealand to the coast of Asia.

"The importance of a trade employing I00 ships, averaging 4000 tons, manned by thirty or thirty-five seamen, and carrying 2000 barrels each, may be readily estimated."

On the same page is a description of a flood of the Ohio, which inundated Shawnee Town in Illinois. The proprietor of the Illinois Gazette, being taken by surprise in the lower part of his establishment, hastily gathering together such movables as he could lay his 


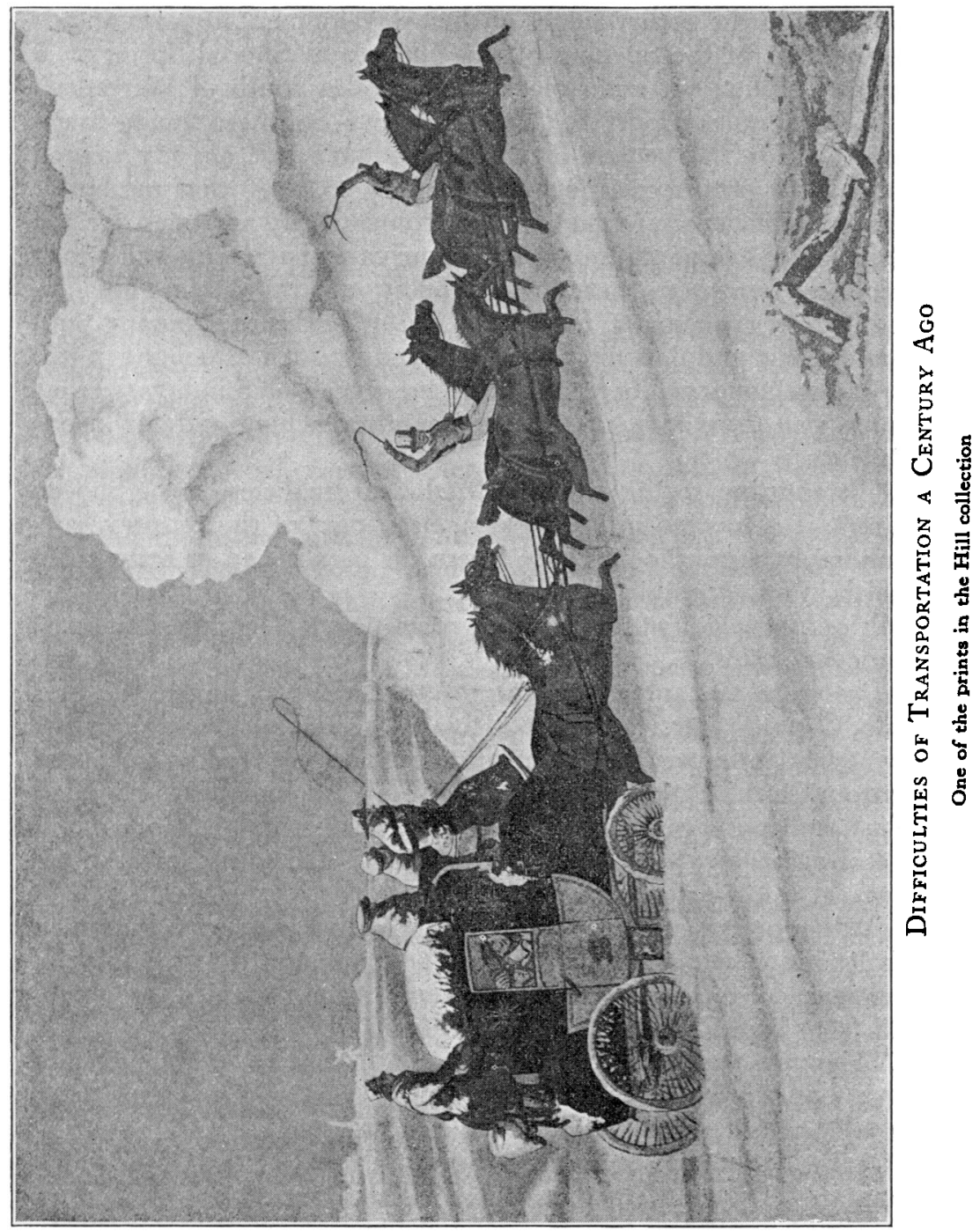


hands on, took refuge in the upper story, where he was confined, in company with a dog, for over a week. Provisions were handed up to him on an oar. After the flood had subsided, the inhabitants had lost count of time, and "were in a dilemma as to the day of the week."

Among the earlier clippings, mounted but unbound, lists of goods for sale at the offices of merchant shipping firms, or at public auction, show the types of cargoes coming to the American ports before the War of $I_{8}$ I $_{2}$ had shaken and wellnigh ruined the old order of the Canton, East and West India trades: molasses, sugar and a few pipes of first proof Amsterdam gin, "now landing from the Sloop Three Brothers," a West India cargo; Bohea, Souchong and Hyson Teas, from Canton, New Orleans and Georgia cotton, raisins, lemons, and "qr casks of Malaga Wine," from Spain; fine bastas, Chittahully ditto, Jallapore malmoody, Allabad emertee, chintzes, taffeties, and Bandanna, Lungee and Suttafoy handkerchiefs, India goods, "to be sold tomorrow at 9 o'clock, at liberal credit, at the new brick Store, No. 5 Central Wharf."

News received by the "marine telegraph," a system of semaphores from Martha's Vineyard to Boston Harbor, of arrival of ships at the Vineyard is included, with the promise that "telegraph" service will be extended to Salem, if the attitude of that city is sufficiently encouraging. The mechanics of New York are reported to have held a meeting for the suppression of a Bread Company as a dangerous monopoly. Conservative Boston, through its newspapers, holds up its hands in horror at the impious desire of the "Jacobins," (sympathisers with the French Revolutionists, or anyone caught holding liberal opinions), to have England revolutionized, prophesying horrid results if such a thing should ever happen. Five hundred dollars reward is offered by the Selectmen, Charles Bulfinch, Chairman, for the detection of incendiaries who set fire to the wharves near Fifth-Street, as the fires are supposed to be the "effect of design."

These few extracts serve to give a sample of the sort of information, enlightening or entertaining, in these clippings. Among them there is perhaps no startling discovery which will add a new element to business history. They do, however, bring out the smaller and more intimate details of the development of transportation and its allied activities, through the medium of daily popular comment. 